\title{
A decisão de voto do eleitor catarinense (1998-2006)
}

\author{
The voter's decision in Santa Catarina
}

(1998-2006)

\author{
Yan de Souza Carreirão*
}

\begin{abstract}
Resumo: O objetivo deste artigo é analisar os fatores que são relevantes na decisão de voto dos eleitores catarinenses. Isso é feito com base em dados de pesquisas eleitorais realizadas entre 1998 e 2006, analisando as possíveis associações entre as intenções de voto dos eleitores catarinenses e um conjunto significativo de variáveis, de natureza socioeconômica (sexo, idade, ocupação, escolaridade, renda, "raça"/cor e religião dos eleitores) e política (preferência partidária e avaliação de desempenho dos governantes), para os cargos de presidente, governador e senador, nas três últimas eleições gerais.
\end{abstract}

Palavras-chave: Comportamento eleitoral; Eleições em Santa Catarina

\begin{abstract}
This article analyzes the relevant factors for the voter's decision in Santa Catarina. This study is carried out based on electoral surveys applied between 1998 and 2006. It analyzed the possible associations between a significant set of socioeconomic (gender, age, schooling, income, race and religion) and political (party identification and incumbent evaluation) variables and the voter's intention for president, governor and senator in Santa Catarina. The analysis shows that the socioeconomic variables age, occupation, race, schooling, and income are related to the vote, although not always with the same intensity and direction in relation to the two last variables. As regards party identification, although less than half of the voters expose this identification, among them there is a reasonable association between their identification and their vote. Indeed, the most relevant variable was the incumbent evaluation, that is, voters who evaluate well an incumbent tend to vote for the candidate that represents the continuity of this administration; voters who evaluate an incumbent as a bad one tend to vote for the opposition candidates.
\end{abstract}

Key words: Electoral behavior; Elections in Santa Catarina; Incumbent evaluation; Party identification

* Doutor em Ciência Política pela USP, São Paulo, Brasil, professor na Ufsc, Florianópolis, Brasil e pesquisador do CNPq. Este trabalho é fruto de pesquisa apoiada pelo CNPq através de Bolsa de Produtividade (Proc. no 306413/2004-3) e de Financiamento (Edital CH 32 - 2004; Proc. no 401994/2004-0).<dozol.carreirao@uol.com.br>

\begin{tabular}{|c|c|c|c|c|c|}
\hline Civitas & Porto Alegre & v. 8 & n. 2 & p. 207-236 & maio-ago. 2008 \\
\hline
\end{tabular}


O objetivo deste artigo é analisar os fatores que são relevantes na decisão de voto dos eleitores catarinenses. Isso é feito com base em dados de pesquisas eleitorais realizadas entre 1998 e 2006. ${ }^{1}$ Entre as limitações desta análise, a primeira é a indisponibilidade de pesquisas eleitorais anteriores às eleições de 1998. Para as eleições de 1998 em diante, um problema muito relevante é relativo ao tipo de dados ali presentes: o fato de não termos nenhuma pesquisa realizada em âmbito acadêmico limita muito a análise, na medida em que os institutos de pesquisa, mesmo prestando um grande serviço à investigação acadêmica (ao tornar seus dados disponíveis), têm objetivos que diferem, em parte, dos interesses dos pesquisadores acadêmicos. Disso resulta, na maioria das vezes, a formulação de questionários que não englobam todas as variáveis que deveriam ser introduzidas, de forma a testar modelos mais complexos de comportamento do eleitor. Além disso, há variações na formulação dos questionários entre uma eleição e outra e mesmo entre duas pesquisas relativas a uma mesma eleição, novamente dificultando o teste de um mesmo modelo para mais de uma eleição.

De toda forma, foi feito aqui um esforço de analisar possíveis associações entre as intenções de voto dos eleitores catarinenses e um conjunto significativo de variáveis, de natureza socioeconômica (sexo, idade, ocupação, escolaridade, renda, "raça"/cor e religião dos eleitores) e política (preferência partidária e avaliação de desempenho dos governantes), para os cargos de presidente, governador e senador, nas três últimas eleições gerais. $^{2}$

Quanto a estas variáveis, a literatura brasileira recente tem apontado que há variações significativas na influência das variáveis socioeconômicas dos eleitores sobre seu voto. Considerando as eleições presidenciais de 1989 para cá, enquanto a variável sexo tem tido pouca relevância na decisão de

\footnotetext{
1 Os dados de pesquisas aqui utilizados foram produzidos por institutos de pesquisa (Ibope e Datafolha). Alguns destes dados foram coletados diretamente nos sites destes institutos, enquanto os demais foram adquiridos junto ao Centro de Estudos de Opinião Pública (Cesop - Unicamp), que armazena e torna disponíveis estes dados ao público. Agradeço aos institutos por tornarem públicos seus dados e ao Cesop (especialmente nas pessoas de Rachel Meneguello, Simone Aranha e Rosilene S. Gelape) pela gentileza e agilidade no atendimento de minhas demandas.

2 Algumas das variáveis que têm sido estudadas em âmbito nacional não poderão ter analisada sua possível influência na decisão de voto dos catarinenses, por absoluta ausência de questões relativas a estas variáveis nos questionários das pesquisas disponíveis para este estudo. É o que acontece com a "identificação ideológica" dos eleitores (Singer, 2000; Carreirão, 2002b e Almeida, 2001, entre outros) e da avaliação que os eleitores fazem de atributos pessoais dos candidatos (Rahn et al., 1990; Popkin, 1994; Figueiredo, 1994; Carreirão, 2002a). As limitações apontadas tornam pouco úteis análises mutivariadas.
} 
voto, em certas ocasiões a idade dos eleitores pode ter alguma influência, mas nem sempre no mesmo sentido. No que se refere às clivagens de escolaridade e renda, mostraram-se relevantes para diferenciar o voto nas eleições presidenciais de 1989 e 2006, mas não foram muito relevantes nas eleições de 1994, 1998 e 2002. Além disso, a influência destas variáveis sobre o voto em 2006 teve sentido oposto ao que teve em 1989. Em 2006, foi entre os eleitores menos educados e eleitores das regiões mais pobres que a avaliação do governo foi mais positiva e maior a votação em Lula. Estas tendências seguem o esperado por certa literatura (Lipset, 1967; Soares, 1973 e 2001): os mais pobres (e menos educados) tendem a votar nas opções à esquerda (pelo menos se considerarmos o confronto, em 2006, entre os dois candidatos com chances reais na disputa). Isso difere do que aconteceu na eleição presidencial de 1989, em que Collor foi eleito basicamente com o apoio dos mais pobres e menos educados (ver, para tentativas de explicação deste fenômeno, Carvalho, 1989 e Singer, 1990). Foi também na eleição presidencial de 2006, muito mais do que em qualquer outra, que destacou-se uma tendência clara de diferenciação do voto, segundo a "raça", ou "cor" dos eleitores: a votação de Lula foi muito maior entre pretos e pardos do que entre os brancos (Carreirão, 2007b).

Por outro lado, teses sobre a avaliação de desempenho do governo sobre a decisão de voto são abundantes na literatura (Key, 1966; Fiorina, 1981; Lewis-Beck, 1988; Carreirão, 1999 e 2002a; Echegaray, 2005, dentre outros). Quanto à eventual relevância da preferência partidária sobre o comportamento político dos eleitores, não há consenso nem na literatura internacional (Clarke e Stewart, 1998; Dalton e Wattenberg, 2000; Weisberg e Greene, 2003; entre outros), nem na nacional (Singer, 2000, Carreirão e Kinzo, 2004; Veiga, 2007; Rennó, 2007, entre outros).

\section{As eleições de 1998}

Antes de iniciar a análise de dados de pesquisas eleitorais, é importante conhecer os resultados oficiais das eleições. Em Santa Catarina, na eleição presidencial, o então presidente Fernando Henrique Cardoso (FHC) fez $42,6 \%$ dos votos, contra $31,6 \%$ de Lula e $8,6 \%$ de Ciro Gomes. Na eleição para governador, decidida no 1 을 turno, Esperidião Amin (PPB) venceu por larga margem o então governador peemedebista Paulo Afonso Vieira (48,6\% e $19,1 \%$, respectivamente), ficando em 3 ㅇ lugar o candidato petista Milton Mendes. Esta grande diferença deve-se, certamente, ao envolvimento do governador em exercício no chamado "escândalo dos precatórios" (ou "caso 
das Letras"): acusado de improbidade, escapou por pouco de ter seu mandato cassado num processo de impeachment (ver Pereira, 1997). Na eleição para o Senado, foi eleito, com 36,9\% dos votos Jorge Konder Bornhausen (PFL), seguido pelo ex-deputado Valdir Colatto (PMDB), com 19,7\% e pelo ex-prefeito de Florianópolis, Sérgio Grando (PPS), com 17,7\% dos votos.

No que se refere ao voto para presidente, o sexo dos eleitores teve pouca influência sobre suas intenções de voto; quanto à idade, a única variação significativa foi em relação a Lula, cuja intenção de voto (nos dois turnos) caía sistematicamente à medida que se passava dos mais jovens para os mais velhos. ${ }^{3}$ As intenções de voto variaram também com a ocupação dos eleitores, cabendo enfatizar a boa votação do presidente FHC junto aos empresários ( $73 \%$ das intenções de voto neste segmento) e seu baixo desempenho entre funcionários públicos e profissionais liberais, únicas categorias em que não vencia. Quanto a Lula, ia muito mal entre os empresários (apenas $15 \%$ das intenções de voto nesta categoria); seu melhor desempenho era entre os funcionários públicos $(41 \%){ }^{4}$

No que se refere à escolaridade dos eleitores, as principais variações se dão em relação a Ciro Gomes, cuja votação aumentava junto com a escolaridade dos eleitores. Lula tem variações muito pequenas e FHC tem apenas uma variação maior, entre os eleitores de nível superior, onde declina um pouco em relação à sua média $(46,4 \%)$. As tendências para $\mathrm{FHC}$ e Lula não são muito diferentes no $2^{\circ}$ turno, onde a escolaridade não é uma variável relevante na "explicação" do voto.

$\mathrm{Na}$ Tabela 1 vemos a distribuição das intenções de voto, no 1 을 turno, segundo a renda dos entrevistados. Aqui as tendências são mais nítidas: com poucas oscilações, as votações de Ciro Gomes e do presidente FHC crescem continuamente à medida que cresce a renda dos eleitores. Já com Lula ocorre o oposto: sua votação declina continuamente à medida que passamos dos eleitores mais pobres para os mais ricos. ${ }^{5}$

3 A análise do comportamento eleitoral nas eleições de 1998 será baseada, sempre que possível, numa pesquisa aplicada pelo Datafolha em 24 de setembro de 1998, porque é, das pesquisas disponíveis para nossa análise, a mais próxima da data da realização do 10 turno. Quando necessário, serão utilizadas também outras duas pesquisas, realizadas pelo Ibope em 17/09/98 e pelo Datafolha, entre 17 e 18/09/98.

4 Dados relativos às intenções de voto no 10 turno. Embora com variações nos percentuais, as tendências mais gerais são válidas para as intenções de voto no 2 을 turno. Devido às restrições de espaço, nem todos os dados analisados serão apresentados em tabelas.

5 Os dados referentes às intenções de voto no 2 으 turno (da pesquisa Datafolha de 17 e 18/09/98), porém, apresentam tendências bem menos nítidas: as variações de intenção de voto em FHC e Lula, segundo a renda dos eleitores, são estatisticamente não significativas. 
Tabela 1: Intenções de voto nos principais candidatos a presidente, segundo a renda dos eleitores (1을 turno -1998$)(\%)$

\begin{tabular}{lcccccc}
\hline \multirow{2}{*}{ Candidato } & \multirow{2}{*}{ Total } & \multicolumn{5}{c}{ Renda (em Salários Mínimos) } \\
\cline { 3 - 7 } & & Até $\mathbf{2}$ & $\mathbf{+ 2}$ a 5 & $+\mathbf{5}$ a 10 & + 10 a 20 & + de 20 \\
\hline Ciro Gomes & 7,9 & 5,1 & 5,0 & 9,6 & 14,8 & 13,8 \\
FHC & 46,4 & 37,8 & 45,9 & 51,2 & 48,9 & 53,9 \\
Lula & 29,6 & 35,3 & 31,4 & 27,3 & 24,4 & 23,5 \\
\multicolumn{1}{c}{$(\mathrm{N})$} & $(1508)$ & $(275)$ & $(518)$ & $(385)$ & $(176)$ & $(97)$ \\
\hline
\end{tabular}

Fonte: Datafolha $(24 / 09 / 1998)(\mathrm{N}=1508)$.

A preferência partidária dos eleitores e a possível associação entre esta preferência e a intenção de voto para presidente em Santa Catarina ${ }^{6}$ são apresentadas na Tabela 2: 16,7\% dos eleitores manifestavam preferência pelo PMDB; 9,4\% pelo PPB; 8,3\% pelo PT; 5,6\% pelo PFL; 1,9\% pelo PSDB e pelo PDT. $^{7}$ Cerca de $54 \%$ dos eleitores não manifestavam preferência por nenhum partido (dado muito próximo aos que as pesquisas em âmbito nacional apontavam no período próximo a eleição de 1998). ${ }^{8}$

Tabela 2: Intenções de voto nos principais candidatos a presidente, segundo a preferência partidária dos eleitores (1ำ turno - 1998)

\begin{tabular}{lcccccccc}
\hline \multirow{2}{*}{ Candidato } & \multicolumn{8}{c}{ Preferência Partidária } \\
\cline { 2 - 9 } & PMDB & PT & PPB & PFL & PSDB & PDT & Outros & Sem pref.* \\
\hline Ciro Gomes & 10,8 & 3,2 & 7,8 & 8,3 & 10,3 & 10,3 & 14,3 & 7,2 \\
FHC & 46,2 & 4,8 & 66,0 & 56,0 & 75,9 & 37,9 & 42,9 & 40,6 \\
Lula & 31,3 & 83,1 & 18,4 & 25,0 & 6,9 & 44,8 & 32,2 & 23,7 \\
\multicolumn{1}{c}{$(\mathrm{N})$} & $(251)$ & $(124)$ & $(141)$ & $(84)$ & $(29)$ & $(29)$ & $(28)$ & $(822)$ \\
\hline
\end{tabular}

Fonte: Datafolha $(24 / 09 / 1998)(\mathrm{N}=1508)$.

* Eleitores sem preferência partidária (ou que indicaram nomes de pessoas, na resposta).

6 Em âmbito nacional, Carreirão e Kinzo (2004) mostram que é justamente em 1998 que o PT ultrapassa, na preferência do eleitorado, o PMDB (partido com maior preferência desde 1989, pelo menos); em setembro, pesquisa nacional do Datafolha apontava $15 \%$ de preferência pelo PT; $12 \%$ pelo PMDB; $6 \%$ pelo PFL e $4 \%$ pelo PSDB (não havendo dados para PPB e PDT naquela pesquisa. De toda forma, a série histórica indicava em torno de $2 \%$ para o PDT e $1 \%$ para o PPB, nas pesquisas próximas a setembro de 1998).

7 O percentual de preferência de cada partido é calculado, a partir dos dados de cada tabela, dividindo o número absoluto de eleitores (na última linha) que manifestam preferência pelo partido pelo número total de eleitores da amostra.

$8 \mathrm{Na}$ realidade, há certa variação entre as pesquisas realizadas nos 10 e 20 turnos: na primeira delas o PPB aparece à frente do PT na preferência dos eleitores, enquanto na segunda ocorre o inverso; a preferência pelo PSDB aumenta um pouco entre as duas pesquisas. 
Assim, embora haja certas semelhanças entre as tendências relativas às preferências partidárias dos eleitores catarinenses e brasileiros, os dados revelam também certas especificidades do âmbito estadual. Inicialmente, em Santa Catarina o PMDB ainda continuava sendo, de longe, o partido com maior preferência (quase o dobro do PT), enquanto no país o PT já predominava. Um segundo aspecto importante é a preferência pelo $\mathrm{PPB}$, que em Santa Catarina alcança cerca de 9\%, enquanto no nível nacional a preferência pelo partido era residual: só $1 \%$ dos eleitores preferia o partido. Isso está em consonância com o grau de estruturação do PPB e com a relevância estadual dos grandes líderes do partido (especialmente Esperidião Amin, àquela época). A preferência pelo PSDB em Santa Catarina era relativamente menor do que no conjunto do país, expressando, também, a debilidade do partido, que só a partir de 2002, principalmente, vai se estruturar melhor em âmbito regional. Em relação ao PFL e ao PDT não há discrepância entre os âmbitos estadual e nacional.

No que se refere à associação entre preferência partidária e voto, as tendências são mais semelhantes ao que ocorre no país como um todo: entre os $45 \%$ de eleitores que manifestavam preferência por algum partido, a grande maioria dos "eleitores do PT" $91 \%$ no $\left.2^{\circ}\right)$; boa parte dos eleitores peessedebistas votava em FHC $(76 \%$ e 79\%, respectivamente). Entre os eleitores com preferência pelos demais partidos a associação era menor, mas ainda significativa para o PFL e para 0 PP, em que predominava por boa margem o voto em FHC, especialmente no $2^{\circ}$ turno. ${ }^{10}$ Entre os eleitores do PMDB a maioria relativa votava também em FHC e no PDT a maioria votava em Lula. Mas, a associação aí já era bem menor entre as duas variáveis. Grosso modo, estas são também as tendências em âmbito nacional.

Na Tabela 3 são mostrados dados cuja finalidade é verificar o grau de associação entre a avaliação que os eleitores faziam do governo do presidente FHC e suas intenções de voto.

\footnotetext{
9 É importante ter claro que a expressão "eleitores do PT" (do PSDB, etc.) não indica o voto efetivo no candidato do PT, mas a preferência manifestada pelo partido. Apenas por economia de linguagem será utilizada este tipo de expressão, no lugar de "eleitores que manifestavam preferência pelo PT" (PSDB, etc.).

${ }^{10}$ Não foi apresentada uma tabela com dados para o 2 은 turno por problemas de espaço.
} 
Tabela 3: Intenção de voto para presidente, segundo avaliação de desempenho do presidente FHC (1ํo turno - 1998)

\begin{tabular}{lcccccc}
\hline \multirow{2}{*}{ Candidato } & \multirow{2}{*}{ Total } & \multicolumn{5}{c}{ Avaliação do presidente FHC } \\
\cline { 3 - 7 } & & Ótimo & Bom & Regular & Ruim & Péssimo \\
\hline Ciro Gomes & 7,9 & 2,3 & 4,8 & 11,0 & 8,3 & 9,1 \\
FHC & 46,4 & 86,0 & 73,9 & 38,4 & 5,8 & 3,0 \\
Lula & 29,6 & 4,7 & 12,7 & 29,2 & 71,7 & 64,2 \\
\multicolumn{1}{c}{$(\mathrm{N})$} & $(1508)$ & $(86)$ & $(505)$ & $(617)$ & $(120)$ & $(165)$ \\
\hline
\end{tabular}

Fonte: Datafolha $(24 / 09 / 1998)(\mathrm{N}=1508)$.

Dos 1508 entrevistados, 39,2\% avaliavam o governo FHC como ótimo ou bom; $40,9 \%$ como regular e $18,9 \%$ como ruim ou péssimo. Era uma avaliação com um predomínio de avaliações positivas em relação às negativas, embora "regular" fosse a avaliação mais comum. Havia uma forte associação entre a avaliação que os eleitores faziam do governo FHC e seu voto para presidente. Quando passamos dos eleitores que avaliavam o governo como ótimo para os que o avaliavam como péssimo, as intenções de voto em FHC declinavam sistematicamente (de $86 \%$ para apenas $3 \%$ dos votos), enquanto a tendência mais geral era de crescimento das intenções de voto em seus adversários. Uma análise de correlação aponta alto coeficiente de correlação entre as duas variáveis. ${ }^{11} \mathrm{~A}$ associação é ainda maior no que se refere às intenções de voto no $2^{\circ}$ turno: enquanto entre os eleitores que avaliavam o governo como ótimo FHC vencia Lula por uma diferença de $93 \%$, Lula vencia seu adversário por $77 \%$ entre os eleitores que avaliavam o governo como péssimo. ${ }^{12}$

Em geral, a suposição é a de que a avaliação que o eleitor faz de um governo influencia seu voto na próxima eleição para este cargo. Mas, é possível que a avaliação que ele faz do governo seja influenciada previamente por suas inclinações políticas (uma das quais, sua preferência partidária).

${ }^{11}$ Coeficiente de correlação (gama de Goodman e Kruskal) de 0,80, quando a variável intenção de voto era operacionalizada apenas com duas categorias: FHC x demais candidatos; de 0,71 quando operacionalizada com três categorias: FHC; brancos/nulos/NS; demais candidatos. A variável avaliação do governo $\mathrm{FHC}$ foi operacionalizada com três categorias: ótimo/bom; regular; ruim/péssimo.

12 Coeficiente de correlação (gama) de 0,88 , quando a variável intenção de voto era operacionalizada apenas com duas categorias: FHC x Lula; de 0,80 quando operacinalizada com três categorias: FHC; brancos/nulos/NS; Lula. Embora os dados não sejam mostrados aqui, a avaliação que os eleitores faziam do Plano Real mantinha este mesmo tipo de associação com o voto, descrito acima. 
De forma a aprofundar a análise e verificar esta última hipótese, a Tabela 4 mostra dados relativos às associações entre estas variáveis.

Tabela 4: Intenção de voto para presidente, segundo preferência partidária e avaliação do presidente FHC ( 2 o turno - 1998)

\begin{tabular}{lccccc}
\hline \multirow{2}{*}{ Prefer. Partid. } & \multirow{2}{*}{ Candidato } & \multirow{2}{*}{ Total } & \multicolumn{3}{c}{ Avaliação do presidente FHC } \\
\cline { 4 - 6 } PMDB & & Ótimo/Bom & Regular & Ruim/Péssimo \\
\hline \multirow{4}{*}{ FHC } & 54,7 & 86,7 & 48,5 & 8,3 \\
PT & Lula & 38,1 & 11,1 & 42,3 & 79,2 \\
& $(\mathrm{~N})$ & $(236)$ & $(90)$ & $(97)$ & $(48)$ \\
& FHC & 6,2 & 40,0 & 5,6 & 1,3 \\
PPB & Lula & 91,0 & 60,0 & 88,9 & 97,4 \\
& (N) & $(145)$ & $(10)$ & $(54)$ & $(79)$ \\
& FHC & 67,3 & 88,5 & 60,0 & 0 \\
PSDB & Lula & 24,8 & 7,7 & 32,0 & 72,7 \\
& (N) & $(113)$ & $(52)$ & $(50)$ & $(5)$ \\
& FHC & 78,8 & 96,2 & 78,9 & 16,7 \\
PFL & Lula & 17,3 & 3,8 & 21,1 & 50,0 \\
& (N) & $(52)$ & $(26)$ & $(19)$ & $(6)$ \\
& FHC & 72,5 & 92,5 & 71,8 & 8,3 \\
& Lula & 22,0 & 7,5 & 23,1 & 66,7 \\
& (N) & $(91)$ & $(40)$ & $(39)$ & $(12)$ \\
\hline
\end{tabular}

Fonte: Datafolha (17 e 18/09/1998) $(\mathrm{N}=1508)$.

Os dados revelam certo grau de influência da preferência partidária dos eleitores sobre a avaliação que faziam do governo FHC. O contraste se dá especialmente entre os adeptos do PT, de um lado e os do PSDB (e, em menor grau, do PPB e do PFL) de outro. Enquanto entre os eleitores com preferência por estes últimos partidos a porcentagem de eleitores que avaliavam o governo positivamente era significativamente maior do que na média da amostra (no PSDB, por exemplo, esta porcentagem era de $50 \%$, contra $37 \%$ do conjunto dos entrevistados), no PT ocorria o inverso: apenas 7\% avaliava o governo positivamente, contra $54 \%$ que o avaliavam negativamente. ${ }^{13}$ Entre os eleitores com preferência por outros partidos, a avaliação não diferia muito da do conjunto da amostra.

$\mathrm{Na}$ realidade, os dados mostram a influência simultânea da preferência partidária e da avaliação de governo sobre as intenções de voto

\footnotetext{
${ }^{13}$ Estes percentuais são calculados a partir dos números absolutos mostrados na última linha relativa a cada partido.
} 
no $2^{\circ}$ turno: a influência das preferências partidárias se manifesta não só no percentual de eleitores de cada partido que avaliavam o governo positiva ou negativamente (o que já havia sido visto na tabela anterior), mas, também, no fato de que, mesmo entre eleitores que avaliam o governo da mesma forma, as intenções de voto em FHC são menores entre os "eleitores petistas" e maiores nos peessedebistas, com percentuais intermediários nos demais partidos.

Assim, no conjunto dos eleitores que avaliavam o governo FHC positivamente, entre os "petistas", FHC tinha apenas $40 \%$ dos votos, enquanto tinha 96\% dos "peessedebistas"; no conjunto de eleitores que avaliavam o governo FHC negativamente, FHC tinha 16\% de votos entre os eleitores com preferência pelo seu partido, enquanto tinha apenas $1 \%$ entre os "eleitores petistas". Por outro lado, entre os eleitores que avaliavam o governo como péssimo ou ruim, Lula vencia por boa margem, independentemente da preferência partidária dos eleitores. Deve-se observar, porém, que mesmo entre os que tinham uma avaliação positiva do governo, Lula vencia entre os petistas. Ou seja, a força da preferência partidária entre os "eleitores petistas" sobrepuja a força da avaliação de governo, na decisão de voto. Em relação aos demais partidos as duas variáveis parecem ter peso mais equilibrado.

Até aqui foram analisadas as intenções de voto para presidente. A seguir serão apresentados dados relativos às preferências eleitorais para governador. De forma semelhante à eleição para presidente, o sexo dos eleitores tem pouca associação com o voto (nos dois turnos). Além disso, no que se refere à idade, novamente a única variação relevante é nas intenções de voto do candidato petista (Milton Mendes), que declinam com a idade dos eleitores: entre os mais jovens (16 e 17 anos), o candidato tinha cerca de $23 \%$ dos votos, enquanto entre os mais velhos (60 anos ou mais), tinha apenas $3 \%$ dos votos. Uma tendência, que ocorre também na maioria dos casos (para outros cargos e outros anos eleitorais), é o de haver menores percentuais de votos brancos e nulos entre os mais jovens.

Quanto à ocupação dos eleitores, Amin (que tinha 52,3\% das intenções de voto na amostra) teve seu melhor desempenho entre os empresários (71\% nesta categoria) e o pior entre os profissionais liberais (14\%); Paulo Afonso (21,3\% no conjunto do eleitorado) foi melhor entre os autônomos registrados $(30 \%)$, não tendo sequer um eleitor entre os profissionais liberais (embora o número muito pequeno de casos nesta categoria impeça conclusões mais sólidas); foi mal, também, entre os funcionários públicos (12\%). O candidato petista (Milton Mendes, com 10\% das intenções de 
voto), de maneira inversa a Paulo Afonso, foi melhor justamente entre estas duas categorias - profissionais liberais (43\%) e funcionários públicos (19\%), tendo seu pior desempenho entre os empresários $(2 \%)$.

A influência da escolaridade dos eleitores em seu voto é mostrada na Tabela 5 .

$\mathrm{O}$ candidato petista tem sua votação aumentada, à medida que cresce a escolaridade dos eleitores, de tal forma que sua votação entre os eleitores com nível superior de escolaridade era cerca de quatro vezes sua votação entre os eleitores com primário incompleto. A tendência de Paulo Afonso (PMDB) é inversa a de Milton Mendes (PT): sua votação declina com o aumento da escolaridade dos eleitores. Amin (PPB) tem uma oscilação menor e sem sentido único.

Tabela 5: Intenções de voto nos principais candidatos a governador, segundo a escolaridade dos eleitores (1998)

\begin{tabular}{lccccc}
\hline \multirow{2}{*}{ Candidato } & Total & \multicolumn{4}{c}{ Escolaridade } \\
\cline { 3 - 6 } & & $\begin{array}{c}\text { Primário } \\
\text { Incompl. }\end{array}$ & $\begin{array}{c}\text { Primário completo/ } \\
\text { Ginasial completo }\end{array}$ & Colegial & Superior \\
\hline Amin (PPB) & 52,3 & 51,1 & 50,2 & 57,7 & 47,5 \\
Milton Mendes (PT) & 10,1 & 4,4 & 7,7 & 13,6 & 22,7 \\
Paulo Afonso (PMDB) & 21,3 & 25,2 & 25,4 & 14,8 & 14,2 \\
\multicolumn{1}{c}{$(\mathrm{N})$} & $(1508)$ & $(321)$ & $(613)$ & $(433)$ & $(141)$ \\
\hline
\end{tabular}

Fonte: Datafolha (24/09/1998) (N=1508).

Quanto à variável renda, o candidato petista tem sua votação aumentada, à medida que cresce a renda dos eleitores, com exceção da última faixa de renda, onde ocorre um declínio, em relação à faixa anterior. De toda forma, sua votação nas faixas de maior renda era bem superior à que obtinha nas camadas mais pobres do eleitorado. Com uma única exceção, a tendência é de crescimento das intenções de voto em Amin, à medida que passamos dos mais pobres para os mais ricos; a tendência de Paulo Afonso é inversa. ${ }^{14}$

A Tabela 6 indica a associação existente entre a avaliação de desempenho que os eleitores faziam do governador em exercício (Afonso) e suas intenções de voto.

\footnotetext{
${ }^{14}$ As tendências de voto para o $2^{\circ}$ turno segundo escolaridade e renda seriam semelhantes às do $1^{\circ}$ turno para Amin e Paulo Afonso.
} 
Tabela 6: Intenção de voto para governador, segundo avaliação de desempenho do governo em exercício (1998)

\begin{tabular}{lcccccc}
\hline \multirow{2}{*}{ Candidato } & \multirow{2}{*}{ Total } & \multicolumn{5}{c}{ Avaliação do governo Paulo Afonso } \\
\cline { 3 - 7 } & & Ótimo & Bom & Regular & Ruim & Péssimo \\
\hline Milton Mendes (PT) & 7,5 & 2,9 & 5,3 & 9,2 & 7,9 & 8,6 \\
Amin (PPB) & 50,1 & 23,2 & 24,5 & 52,8 & 68,6 & 68,3 \\
P. Afonso (PMDB) & 18,1 & 58,0 & 47,5 & 12,9 & 2,1 & 0,9 \\
\multicolumn{1}{c}{$(\mathrm{N})$} & $(1600)$ & $(69)$ & $(322)$ & $(618)$ & $(191)$ & $(325)$ \\
\hline
\end{tabular}

Fonte: Ibope $(17 / 09 / 1998)(\mathrm{N}=1600)$.

OBs: demais candidatos tinham $1 \%$ ou menos de intenção de voto. Cerca de $5 \%$ dos entrevistados não opinaram sobre a avaliação do governo.

A partir dos dados da última linha é possível constatar que apenas $24 \%$ dos eleitores avaliavam o governo como ótimo ou bom; $39 \%$ o avaliavam como regular e 32\% como ruim ou péssimo. A avaliação era predominantemente negativa. As intenções de voto em Paulo Afonso declinavam, à medida que declinava a avaliação de seu governo. A intenção de voto em Amin (nos dois turnos) cresce vigorosamente à medida que passamos dos eleitores que avaliavam bem para os que avaliavam mal o governo de Paulo Afonso. Embora de forma menos clara, fenômeno semelhante acontecia com o voto no candidato petista.

Mas, vale a pena contrastar estes dados com os analisados na Tabela 3, relativa ao cargo de presidente. As intenções de voto em FHC entre os que avaliavam seu governo como ótimo e bom eram bem maiores $(86 \%$ e $74 \%$, respectivamente) do que as encontradas para Paulo Afonso $(58 \%$ e 47,5\%, respectivamente). Ou seja, uma avaliação positiva do governo Paulo Afonso não "rendia" tantos votos quanto uma avaliação positiva "rendia" ao presidente FHC. Em parte isso talvez se deva a que parcela dos eleitores, mesmo avaliando positivamente a gestão de Paulo Afonso, por seus resultados gerais (nas políticas públicas estaduais), poderia ter certa resistência à pessoa do candidato-governador, por seu envolvimento no "escândalo das Letras".

Como mostra a Tabela 7, a preferência partidária pelo $\mathrm{PPB}$, pelo $\mathrm{PFL}$ e pelo PSDB (que faziam parte da coalizão de apoio a Amin) era um forte preditor de voto em Amin; embora com menos intensidade, a preferência pelo PMDB estava associada com o voto em Paulo Afonso (PMDB) e a preferência pelo PT com o voto em Milton Mendes (PT). Os eleitores que manifestavam preferência pelo PDT, ao contrário do que seria de esperar se votassem num candidato de um partido ideologicamente mais próximo ao PDT, votavam majoritariamente em Esperidião Amin. O padrão é semelhante 
ao encontrado na eleição para presidente (Tabela 2): entre os eleitores com preferência por algum partido, a maioria votava no candidato de seu partido, ou do partido mais próximo, ideologicamente, ao seu preferido. Mas, havia também um contingente não desprezível de eleitores com preferência por um partido que não agiam desta forma.

Tabela 7: Intenções de voto nos principais candidatos a governador, segundo a preferência partidária dos eleitores (1998)

\begin{tabular}{lcccccccc}
\hline \multirow{2}{*}{ Candidato } & \multicolumn{7}{c}{ Preferência Partidária } \\
\cline { 2 - 9 } & PMDB & PT & PPB & PFL & PSDB & PDT & Outros & Sem pref.* \\
\hline Amin & 26,3 & 27,4 & 83,7 & 83,3 & 79,3 & 51,7 & 60,7 & 54,3 \\
M. Mendes & 4,8 & 54,0 & 2,1 & 1,2 & 6,9 & 20,7 & 7,1 & 7,2 \\
P. Afonso & 58,6 & 8,9 & 7,8 & 8,3 & 10,3 & 24,1 & 10,7 & 16,1 \\
\multicolumn{1}{c}{$(\mathrm{N})$} & $(251)$ & $(124)$ & $(141)$ & $(84)$ & $(29)$ & $(29)$ & $(28)$ & $(822)$ \\
\hline
\end{tabular}

Fonte: Datafolha (24/09/1998) ( $\mathrm{N}=1508)$.

* Sem preferência partidária (ou que indiquem nomes de pessoas, na resposta à pergunta).

Na eleição para senador, o sexo dos eleitores mais uma vez se mostrou sem influência sobre suas intenções de voto. Embora tenha havido algumas variações nas intenções de voto conforme a idade dos eleitores, não se configurou nenhum padrão claro nas oscilações. Quanto à escolaridade dos eleitores, o voto em Grando (PPS) aumenta à medida que passamos dos eleitores menos escolarizados aos com maior nível de instrução. Em relação aos outros dois candidatos, as variações em torno da média foram menores e não ocorreram num único sentido. Mas, no caso do candidato peemedebista, a tendência mais geral é a de uma melhor votação nas duas faixas de menor escolaridade.

No que respeita à renda (Tabela 8), embora com certas exceções, as tendências mais gerais eram de crescimento das votações de Bornhausen (PFL) e Grando à medida que se passava dos mais pobres aos mais ricos. Já com Colatto (PMDB) a tendência é inversa à dos outros dois candidatos: há um declínio nas intenções de voto neste candidato, especialmente comparando a faixa dos mais pobres com a dos mais ricos.

Quanto ao candidato do PPS, trata-se, portanto, de tendência inversa à esperada pela literatura vinculada à teoria da modernização ou a uma abordagem marxista, que esperaria uma maior votação em candidatos ligados a partidos de esquerda entre os mais pobres. 
Tabela 8: Intenções de voto nos principais candidatos a senador, segundo a renda dos eleitores (1998)

\begin{tabular}{lcccccc}
\hline \multirow{2}{*}{ Candidato } & \multirow{2}{*}{ Total } & \multicolumn{5}{c}{ Renda (em Salários Mínimos) } \\
\cline { 3 - 7 } & & Até 2 & + 2 a 5 & + 5 a 10 & + 10 a 20 & + de 20 \\
\hline Jorge Bornhausen & 38,1 & 32,7 & 37,8 & 42,6 & 38,1 & 44,9 \\
Sérgio Grando & 19,5 & 16,0 & 14,3 & 22,6 & 31,8 & 28,3 \\
Valdir Colatto & 11,8 & 16,7 & 11,0 & 10,6 & 11,4 & 6,9 \\
\multicolumn{1}{c}{$(\mathrm{N})$} & $(1508)$ & $(275)$ & $(518)$ & $(385)$ & $(176)$ & $(97)$ \\
\hline
\end{tabular}

Fonte: Datafolha (24/09/1998) $(\mathrm{N}=1508)$.

A Tabela 9 mostra que as preferências partidárias dos eleitores influenciaram em certo grau também seu voto para senador. $O$ candidato pefelista vence com boa margem entre os eleitores com preferência pelo PSDB, PPB e PFL; o candidato do PPS vence entre os adeptos do PT e do PDT (embora neste último por margem relativamente pequena). Por fim, o candidato do PMDB vence apenas entre os que manifestavam preferência pelo seu partido. Por outro lado, com exceção dos eleitores com preferência por PT, PPB e PFL, há percentuais relevantes de eleitores com preferência pelos demais partidos que votam em candidatos diferentes daqueles de seus partidos (ou de partidos mais próximos, ideologicamente, dos partidos que dizem preferir). Esta última tendência, acrescida do fato de que 54,5\% dos eleitores não manifestavam preferência por nenhum partido indica os limites da influência dos vínculos partidários dos eleitores em sua decisão de voto para senador.

Tabela 9: Intenções de voto nos principais candidatos a senador, segundo a preferência partidária dos eleitores (1998)

\begin{tabular}{lcccccccc}
\hline \multirow{2}{*}{ Candidato } & \multicolumn{7}{c}{ Preferência Partidária } \\
\cline { 2 - 9 } & PMDB & PT & PPB & PFL & PSDB & PDT & Outros & Sem pref.* \\
\hline Bornhausen & 25,9 & 12,1 & 68,8 & 64,3 & 72,4 & 24,1 & 46,4 & 36,6 \\
Grando & 14,7 & 60,5 & 12,8 & 6,0 & 13,8 & 37,9 & 17,8 & 17,0 \\
Colatto & 32,7 & 4,0 & 2,8 & 4,8 & - & 10,3 & 7,1 & 9,5 \\
(N) & $(251)$ & $(124)$ & $(141)$ & $(84)$ & $(29)$ & $(29)$ & $(28)$ & $(822)$ \\
\hline
\end{tabular}

Fonte: Datafolha (24/09/1998) (N=1508).

* Sem preferência partidária (ou que indiquem nomes de pessoas, na resposta à pergunta).

Após a análise, feita acima, das possíveis associações entre diversas variáveis (socioeconômicas e políticas) e as intenções de voto para cada um dos cargos separadamente, serão apresentados dados relativos a cruzamentos 
das intenções de voto a dois cargos simultaneamente, de forma a verificar em que medida os eleitores votam em candidatos de mesmo partido ou pertencentes ao mesmo "campo ideológico" para cargos diferentes numa mesma eleição. ${ }^{15}$

A Tabela 10 mostra uma associação razoável entre as intenções de voto nas eleições para presidente e governador: como seria de esperar (caso houvesse consistência partidária e/ou ideológica do voto), a maioria dos eleitores de Amin votava em FHC e a grande maioria dos eleitores do petista Milton Mendes votava em Lula. Os eleitores de Paulo Afonso (PMDB) se dividiam entre Lula e FHC, com certo predomínio deste último.

Tabela 10: Intenção de voto para presidente, segundo intenção de voto para governador (1998)

\begin{tabular}{|c|c|c|c|}
\hline \multirow{2}{*}{$\begin{array}{c}\text { Candidato a } \\
\text { presidente }\end{array}$} & \multicolumn{3}{|c|}{ Candidato a governador } \\
\hline & Amin & M. Mendes & P. Afonso \\
\hline Ciro Gomes & 7,9 & 9,9 & 9,0 \\
\hline FHC & 60,2 & 11,8 & 44,2 \\
\hline Lula & 22,7 & 70,4 & 35,2 \\
\hline$(\mathrm{N})$ & $(789)$ & $(152)$ & $(321)$ \\
\hline
\end{tabular}

Fonte: Datafolha (24/09/1998) (N=1508).

Os dados relativos ao cruzamento das votações aos cargos de presidente e senador apresentam tendências semelhantes, com pequenas variações: a associação entre FHC (PSDB) e Bornhausen (PFL) é ainda maior do que a encontrada entre Amin (PPB) e FHC; por outro lado, a associação entre Lula e Grando (PPS) é menor do que a existente entre Lula e Mendes. Os eleitores de Colatto (PMDB) se dividem ainda mais entre FHC e Lula do que os eleitores de Paulo Afonso. Também no que respeita ao cruzamento dos votos para governador e senador as tendências são semelhantes às anteriores; no caso do PMDB a associação agora é maior, já que se trata de dois candidatos filiados ao partido (o que não ocorria nos dois cruzamentos anteriores).

Considerando as intenções de voto dos eleitores no 1 e no $2 \underline{0}$ turnos das eleições para presidente e governador, a grande maioria dos eleitores repete, no 2 은 turno, seu voto nos dois principais candidatos a cada cargo, no

\footnotetext{
${ }^{15}$ A noção de "ideologia" será usada aqui de forma muito simplificada, a partir das classificações mais comuns dos principais partidos brasileiros no continuum direita-esquerda (ver Carreirão, 2006, p. 143).
} 
1 o turno. No entanto, no que se refere aos eleitores que pretendiam votar em alguns candidatos que não iriam ao $2^{\mathrm{O}}$ turno, há percentuais significativos de votos "transferidos" a candidatos ideologicamente distantes daqueles em quem eles pretendiam votar no $1 \stackrel{0}{\circ}$ turno. ${ }^{16}$ Assim, a quase totalidade dos eleitores que pretendiam votar em FHC ou Lula para presidente, no 1으 turno,

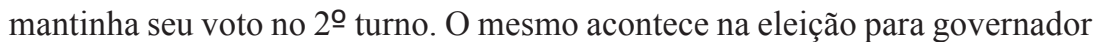
entre os eleitores de Amin e, em menor grau, de Paulo Afonso, já que em relação a este último $8,3 \%$ de seus eleitores no 1 으 turno reverteram seu voto para Amin no 20 turno (contra apenas 3,6\% que fizeram o percurso inverso) (Tabela 11).

\section{Tabela 11: Intenção de voto para governador no $2^{\circ}$ turno, segundo intenção de voto no 1 o turno (1998)}

\begin{tabular}{lcccc}
\hline \multirow{2}{*}{$\begin{array}{c}\text { Intenção de voto } \\
\mathbf{2}^{\mathbf{0}} \text { turno }\end{array}$} & Amin & Paulo Afonso & Milton Mendes & B/N \\
\cline { 2 - 5 } Amin & 92,8 & 8,3 & 45,0 & 41,7 \\
Paulo Afonso & 3,6 & 85,5 & 28,3 & 17,2 \\
B/N/Ns & 3,6 & 6,2 & 26,7 & 14,7 \\
\multicolumn{1}{c}{$(\mathrm{N})$} & $(801)$ & $(289)$ & $(120)$ & $(41)$ \\
\hline
\end{tabular}

Fonte: Datafolha (17 e 18/09/08). Obs: Não foram apresentados os dados relativos aos votos em outros "pequenos" candidatos (no 1을.

Considerando ainda os indecisos, votos nulos e brancos, enquanto $7 \%$ dos eleitores de Amin no 1 으 turno não pretendiam repetir seu voto no 2으 turno, este percentual era o dobro (14,5\%) em relação a Paulo Afonso. O desgaste associado "ao caso das Letras" - desgaste que se acumula no 2o turno, na medida em que, obviamente, o caso é lembrado na campanha do adversário - deve ter contribuído para esta perda maior de votos de Paulo Afonso. Por outro lado, entre os eleitores que pretendiam votar em Enéas para presidente, no $1 \cong$ turno, a parcela que pretendia votar em Lula no $2^{\circ}$ turno era maior do que a que pretendia votar em FHC. Da mesma forma, entre os eleitores que pretendiam votar no candidato do PT a governador (Milton Mendes), a parcela que transferia seu voto a Amin no 20 turno era maior do que a que transferia a Paulo Afonso. Embora parte deste comportamento possa ser explicado pela conjuntura política (a posição

\footnotetext{
${ }^{16}$ Embora só seja apresentada a tabela referente à eleição para governador (de forma a economizar espaço), os dados referentes à eleição presidencial serão também comentados.
} 
oposicionista de Enéas em relação a FHC; a alta rejeição a Paulo Afonso entre o conjunto de eleitores, incluindo os petistas, por conta do "caso das Letras"), permanece o fato de que estes comportamentos dos eleitores não seguem um padrão de consistência ideológica. ${ }^{17}$

É possível concluir, portanto, que houve, em 1998, um grau razoável de consistência ideológica e/ou partidária do voto para diferentes cargos num mesmo processo eleitoral (ou na transferência de votos entre o 1 으 e o 2 o turnos para um mesmo cargo), na medida em que a maioria dos votos dados a um candidato a determinado cargo é dada, na eleição para outro cargo (ou no $2^{\circ}$ turno da eleição para um mesmo cargo), a um candidato de mesmo partido e/ou "campo ideológico". Mas, há, também, percentuais não desprezíveis de eleitores que votavam em candidatos de "campos ideológicos" opostos, o que indica que a consistência ideológica não era tão ampla.

\section{As eleições de 2002}

No 1 으 turno das eleições para presidente, Lula venceu, em Santa Catarina, com 52,1\% dos votos; ou seja, se dependesse do Estado, não haveria 2 은 turno. José Serra fez $21,4 \%$ dos votos, Garotinho $11,3 \%$ e Ciro Gomes $6,6 \%$. No 2 은 turno, Lula vence Serra por $59,1 \%$ a $33,1 \%$ dos votos. No 1 은 turno da eleição para o governo do Estado, o então governador (candidato a reeleição) Esperidião Amin (PPB) obteve o apoio de 36,9\% dos eleitores, contra 27,8\% de Luiz Henrique da Silveira (PMDB) e 25,3\% de José Fritsch (PT). No 2 을 turno há uma reversão, com a vitória apertada de Luiz Henrique (46,7\%, contra 46,1\% de Amin). Quanto à eleição de senador, foi bastante equilibrada, com cinco candidatos com chances de conseguir uma das duas vagas. Acabam se elegendo a ex-deputada estadual petista Ideli Salvatti, com $16 \%$ dos votos e o ex-prefeito de Balneário Camboriú, Leonel Pavan, do PSDB (14,7\%). A seguir vinham Hugo Biehl, do PPB $(14,5 \%)$, Paulo Bornhausen $(13,5 \%)$ e Milton Mendes de Oliveira, do PT $(13,3 \%)$.

Para a análise do comportamento do eleitor catarinense em 2002, serão usados dados de duas pesquisas eleitorais realizadas pelo Ibope. A primeira, realizada antes do 1 을 turno, entre 23 e 25 de setembro de 2002, com 1200 elei-

17 Como atenuante, deve-se ressaltar que o número de casos de voto simultaneamente em Enéas ( 1 은 turno) e Lula ( 2 ㅇturno) é muito pequeno (13), não sendo também grande o $\mathrm{n}$ de casos de voto simultaneamente em Milton Mendes (1 turno) e Amin ( $2^{\circ} \circ$ turno $)$. 
tores catarinenses e a segunda, entre o 1 으 e o $2^{\circ}$ turno, entre 15 e 17 de outubro, com 1600 eleitores. $^{18}$

Inicialmente serão analisados dados relativos à eleição para governador. Assim como na eleição de 1998, não há diferenças estatisticamente significativas entre as intenções de voto de homens e mulheres, para o governo do Estado. A única diferença relevante é que entre as mulheres é maior o percentual das que não sabiam ainda em quem votar.

Quanto à variável idade, no 1 으 turno da eleição de 2002 para governador, com exceção dos eleitores na faixa de 35 a 49 anos, que votaram em Amin em menor proporção do que os demais eleitores, e dos eleitores com 50 anos ou mais, que votaram em Fritsch em menor proporção do que os demais eleitores, não há variações estatisticamente significativas nas intenções de voto, segundo a idade dos eleitores. Já no que se refere ao 20 turno, percebe-se uma tendência de equilíbrio entre Amin e Luiz Henrique entre os eleitores na faixa de 25 a 49 anos, enquanto há uma razoável vantagem para Amin entre os mais velhos e, inversamente, uma grande vantagem para Luiz Henrique entre os mais novos.

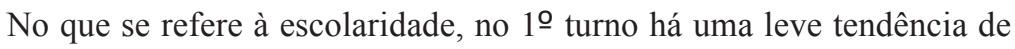
crescimento dos três principais candidatos (Amin, Luiz Henrique e Fritsch), à medida que aumenta a escolaridade dos eleitores. Isso ocorre porque diminui o percentual de indecisos, entre os mais escolarizados. Amin vencia seu principal adversário por boa margem (em torno de 15\%) em todas as faixas de escolaridade. No 2 ㅇ turno, Amin vencia entre os menos e os mais escolarizados, enquanto Luiz Henrique vencia entre os eleitores das faixas intermediárias de escolaridade.

Em relação à renda dos eleitores (Tabela 12), a intenção de voto em Amin oscila pouco, no 1 을 turno; já o voto em Luiz Henrique aumenta sistematicamente com a renda dos eleitores: enquanto entre os mais pobres Amin vencia por $16 \%$ de diferença, havia um empate técnico entre os mais ricos.

\footnotetext{
${ }^{18}$ As intenções de voto para governador no 1 o turno eram: Amin: 40,5\%; Luiz Henrique: 25,1\%; Fritsch: $13 \%$; outros candidatos: $3 \%$; Brancosenulos: $17,2 \%$; nãoresponderam: $1,3 \%$. Nas eleições para senador: Paulinho Bornhausen: 25,2\%; Leonel Pavan: 20,4\%; Casildo Maldaner: 19,1\%; Hugo Biehl: 15,3\%; Ideli Salvatti: 11,7\%. O resultado final, como sabemos, foi bem diferente, com Ideli Salvatti chegando à frente, tendo crescido muito na reta final da disputa. Na pesquisa de 8 a 10/10, no 2 을 turno, Luiz Henrique tinha uma vantagem de $2,5 \%$ sobre seu adversário (46,6\% contra $44,1 \%$ ). Na pesquisa de 15 a $17 / 10 / 02$ os dois candidatos estavam empatados com $44 \%$ das intenções de voto.
} 
Tabela 12: Intenção de voto para governador, segundo a renda dos eleitores (2002)

\begin{tabular}{lcccccccc}
\hline & \multicolumn{3}{c}{ 23 a 25/09/02 (10 turno) } & \multicolumn{3}{c}{ 15 a 17/10/02 (20 turno) } \\
\cline { 2 - 9 } \multicolumn{1}{c}{ Intenção de Voto } & \multicolumn{3}{c}{ Renda (em S. M.) } & \multicolumn{5}{c}{ Renda (em S. M.) } \\
\cline { 2 - 9 } & Até 2 & +2 a 5 & +5 a 10 & + de 10 & Até 2 & +2 a 5 & +5 a 10 & +de 10 \\
\hline Amin (PPB) & 38 & 43 & 41 & 38 & 40 & 44 & 46 & 53 \\
L. Henrique (PMDB) & 22 & 25 & 28 & 37 & 44 & 45 & 48 & 41 \\
Fritsch (PT) & 11 & 11 & 20 & 16 & - & - & - & - \\
Grando (PPS) & 1 & 2 & 2 & 2 & - & - & - & - \\
Outros & 2 & 2 & 0 & 0 & - & - & - & - \\
Br/Nulo/Ns/Nr & 26 & 17 & 9 & 8 & 16 & 11 & 6 & 6 \\
\multicolumn{1}{c}{ Total (N) } & $(328)$ & $(498)$ & $(220)$ & $(90)$ & $(382)$ & $(643)$ & $(312)$ & $(137)$ \\
\hline
\end{tabular}

Fonte: Ibope (23 a 25/09/02 e 15 a 17/10/02).

Fritsch (PT) também melhora significativamente sua votação entre os eleitores com mais de 5 salários mínimos de renda familiar mensal, em comparação com a que obtém entre os mais pobres. No 2 turno há um equilíbrio entre os dois candidatos, com leve vantagem para Luiz Henrique, entre os eleitores cuja renda ia até 10 salários mínimos. Entre os mais ricos, porém, Amin tinha uma grande vantagem. ${ }^{19}$

Como mostra a Tabela 13, a avaliação que os eleitores faziam do governo Amin parece ter sido um fator relevante na decisão de voto: há um declínio sistemático da votação de Amin (nos dois turnos) e um crescimento dos votos nos candidatos da oposição, à medida que passamos dos eleitores com uma avaliação mais positiva do governo Amin, para uma avaliação mais negativa. O coeficiente (Gama) de correlação entre as duas variáveis (avaliação de desempenho do governo Amin e voto) é bastante alto, variando entre 0,70 e 0,85 , dependendo da forma de operacionalização das variáveis, nos dois turnos.

No 2 을 turno, na pesquisa de 15 a $17 / 10$, as porcentagens de eleitores que avaliavam o governo positivamente $(48 \%)$, como regular $(36 \%)$ ou negativamente (11\%) não se modificaram muito em relação à pesquisa de

\footnotetext{
19 Parece ter havido razoável volatilidade das intenções de voto, especialmente entre os eleitores mais escolarizados e ricos, no período entre a pesquisa anterior do Ibope (8 a 10/10/02) e esta pesquisa emanálise (15 a 17/10/02). Napesquisa anterior haviauma inversão:LuizHenrique vencia apenas entre os mais ricos (tendo ali o dobro da votação de Amin), enquanto havia equilíbrio, com pequena vantagem para Amin nas demais faixas de renda. Quanto à escolaridade, naquela pesquisa Amin vencia por pequena margem nas duas faixas de menor escolaridade, enquanto seu adversário vencia por margem significativa nas duas faixas de maior escolaridade.
} 
Tabela 13: Intenção de voto para governador, segundo a avaliação do governo Amin (2002)

\begin{tabular}{lcccccc}
\hline \multirow{2}{*}{$\begin{array}{c}\text { Intenção } \\
\text { de Voto }\end{array}$} & \multicolumn{3}{c}{ 23 a 25/09/02 (10 turno) } & \multicolumn{3}{c}{ 15 a 17/10/02 (20 turno) } \\
\cline { 2 - 7 } & \multicolumn{3}{c}{ Avaliação Gov. Amin } & \multicolumn{3}{c}{ Avaliação Gov. Amin } \\
\cline { 2 - 7 } & Ót./Bom & Regular & Ruim/Pés. & Ót./Bom & Regular & Ruim/Pés. \\
\hline Amin & 69 & 24 & 6 & 68 & 27 & 7 \\
Luiz Henrique & 10 & 34 & 49 & 23 & 61 & 79 \\
Fritsch & 5 & 17 & 28 & -- & -- & -- \\
Grando & 1 & 2 & 2 & -- & -- & -- \\
Outros & 2 & 1 & 2 & -- & -- & - \\
Br/Nulo/Ns/Nr & 14 & 22 & 15 & 9 & 12 & 14 \\
$\quad$ Total (N) & $(544)$ & $(399)$ & $(196)$ & $(767)$ & $(569)$ & $(183)$ \\
\hline
\end{tabular}

Fonte: Ibope.

23 a 25/09 (onde estes percentuais eram 45\%, 33\% e 16\%, respectivamente).

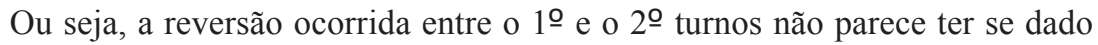
por um crescimento da avaliação negativa do governo Amin entre os eleitores. Da mesma forma, os percentuais de voto em Amin em cada grupo (segundo a avaliação que faziam do governo) não se alteram significativamente, entre o 1 을 o 2 o turno.

A associação entre avaliação de governo e intenção de voto mantémse forte no 2 ㅇ turno, mas talvez não tanto quanto em outras eleições: a desvantagem eleitoral de Amin entre os eleitores que avaliavam seu governo como regular parece maior do que a tendência média de outras eleições. Enfim, mesmo tendo uma avaliação predominantemente positiva de seu governo, Amin não converteu isso numa vitória eleitoral. A campanha do candidato peemedebista, especialmente no $2 \underline{0}$ turno, parece ter conseguido convencer muitos eleitores (inclusive parcela dos que avaliavam positivamente o governo em exercício) de que ele poderia fazer mais pelo Estado do que Amin estava fazendo. Isso, aliado ao decisivo apoio do PT no 2 o turno, talvez possa explicar a reversão nos resultados, ocorrida entre o 1 ㅇ e o 2 o turno da disputa ao governo do Estado em 2002. ${ }^{20}$

A Tabela 14 mostra as intenções de voto dos eleitores no 20 turno, na pesquisa de 15 a 17/10, segundo seu voto declarado (nesta mesma pesquisa) no $1^{\text {O }}$ turno. Como se vê, a grande maioria dos eleitores que disseram ter votado em Amin e Luiz Henrique no 1 으 turno, diziam pretender votar nos mesmos candidatos no 2 ㅇ turno, embora cerca de $7 \%$ dos eleitores de

\footnotetext{
${ }^{20}$ Vale a pena lembrar que o candidato petista fez expressivos $25,3 \%$ dos votos no 10 turno, quase alcançando Luiz Henrique (que obteve apenas $2,5 \%$ a mais).
} 
Luiz Henrique e 11\% dos eleitores de Amin tenham revertido sua intenção de voto (para o candidato adversário) entre o 1 으 e o $2^{\circ}$ turno.

Tabela 14: Intenção de voto 10 turno $\times$ intenção de voto 20 turno (Governador, 2002)

\begin{tabular}{lccccc}
\hline \multirow{2}{*}{$\begin{array}{c}\text { Int. Voto Governador } \\
\text { (20 Turno) }\end{array}$} & Amin & Luiz Henrique & Fritsch & $\begin{array}{c}\text { Outros +Br/ } \\
\text { Nulo/Ns/Nr }\end{array}$ & Total \\
\cline { 2 - 6 } & 82 & 7 & 24 & 27 & 44 \\
\hline Amin & 11 & 89 & 60 & 31 & 44 \\
Luiz Henrique & 8 & 4 & 15 & 42 & 12 \\
Br/Nulo/Ns/Nr & $(687)$ & $(473)$ & $(245)$ & $(195)$ & $(1600)$ \\
\hline \multicolumn{1}{c}{ Total (N) } & & & & &
\end{tabular}

Fonte: Ibope (15 a 17/10/02).

Dos eleitores que votaram em Fritsch no 1 o turno, 3 em cada 5 pretendiam votar em Luiz Henrique no 2 을 turno (seguindo a indicação de apoio do candidato petista). Os eleitores que votaram em outros candidatos, ou anularam ou votaram em branco no 1 으 turno, dividiam-se, quanto ao voto no 2 ㅇ turno. Estes dados mostram o papel fundamental da "transferência" de votos dos eleitores de Fritsch (no 1 을 turno), para a vitória de Luiz Henrique no 2ㅇturno, bem como da "conversão" de votos em Amin no 1으 turno em votos no candidato que acabou vencendo o 2 은 turno.

A análise a seguir visa verificar o grau em que os eleitores votam em candidatos de partidos do mesmo campo ideológico, para diferentes cargos, numa mesma eleição. Inicialmente são apresentados os dados dos cruzamentos entre as intenções de voto para governador e presidente, no 1 으 turno (Tabela 15).

Tabela 15: Intenção de voto para governador, segundo intenção de voto para presidente (1 turno, 2002)

\begin{tabular}{lcccccc}
\hline $\begin{array}{c}\text { Intenção de voto } \\
\text { Governador } \\
\text { (10 turno) }\end{array}$ & Lula & Serra & Ciro & Garotinho & $\begin{array}{c}\text { Outros/Br/ } \\
\text { Nulo/Ns/Nr }\end{array}$ & Total \\
\cline { 2 - 7 } & 37 & 60 & 57 & 47 & 28 & 42 \\
\hline Amin & 28 & 30 & 31 & 32 & 9 & 26 \\
Luiz Henrique & 23 & 2 & 1 & 7 & 1 & 13 \\
Fritsch & 1 & 1 & 7 & 2 & 0 & 1 \\
Grando & 1 & 1 & 0 & 3 & 2 & 1 \\
Outros & 10 & 7 & 4 & 9 & 60 & 17 \\
Br/Nulo/Ns/Nr & $(592)$ & $(197)$ & $(84)$ & $(136)$ & $(191)$ & $(1200)$ \\
$\quad$ Total (N) & & & & & &
\end{tabular}

Fonte: Ibope (23 a 25/09/02). 
No 1을 turno, vemos que Amin tinha maioria (relativa) de votos entre os eleitores de todos os candidatos a presidente. Mas sua vantagem era bem maior entre os eleitores de Serra e Ciro Gomes. Também entre os eleitores de Garotinho, Amin fazia mais votos do que os demais candidatos somados. Já entre os eleitores de Lula, Amin obtinha mais votos que cada um dos candidatos a governador individualmente, mas obtinha 37\% dos votos, contra uma soma de $53 \%$ de intenção de votos para os demais candidatos a governador. Fritsch obtinha sua maior votação naquele momento $(23 \%)$ entre os eleitores de Lula. Mas, ainda assim, era derrotado por Amin e Luiz Henrique mesmo entre estes eleitores.

Quanto ao 20 turno, na pesquisa realizada entre 15 e 17/10, Amin vencia Luiz Henrique por uma diferença de $28 \%$ entre os eleitores de Serra, mas era derrotado por uma diferença de $15 \%$ entre os eleitores de Lula (que eram bem mais numerosos do que os de Serra). Isto resultava, naquele momento, num empate técnico entre os dois candidatos, que se manteve até o final da eleição.

Considerando a proximidade ideológica maior entre PSDB e PMDB e o fato de que em 2002 o PSDB estava formalmente coligado com o PMDB tanto na eleição presidencial quanto na eleição para governador de Santa Catarina, poder-se-ia esperar que a maior parte dos eleitores de Serra tenderia a votar em Luiz Henrique. Mas, outras circunstâncias levavam a outro tipo de "combinação": em primeiro lugar, àquela altura, o PSDB catarinense estava dividido; parcela do partido ainda apoiava Amin (já que o PSDB havia feito parte da coalizão de seu governo, pelo menos até a convenção do partido, na metade de 2002, ter decidido pelo apoio ao candidato do PMDB ao governo do Estado). Além disso, os eleitores "peessedebistas" no Estado não eram muito numerosos; boa parte dos eleitores de Serra no 2 - turno eram eleitores que tradicionalmente votam em candidatos mais à direita e que só tinham Serra como opção no 2o turno. Entre os eleitores de Lula, uma parcela maior votava em Luiz Henrique, mas parcela também significativa (38\%) votava em Amin, até por conta do apoio claro dado pelo candidato peemedebista a Serra.

De modo geral, considerando os dois turnos, embora haja uma tendência maior de voto em Amin entre os eleitores de Serra e uma tendência de maior votação em Luiz Henrique e Fritsch entre os eleitores de Lula, não se pode dizer que haja um alto grau de "consistência" entre o voto para governador e o voto para presidente, se tomarmos o posicionamento ideológico dos partidos envolvidos. Fatores ligados à conjuntura eleitoral, que muitas vezes superam as afinidades ideológicas, parecem ter tido peso relevante nas "combinações" de voto feitas pelos eleitores. 
No que tange ao cruzamento entre as intenções de voto para governador e para senador, no 1을 turno, parece ter havido uma maior "consistência" entre o voto para os dois cargos em análise: entre os eleitores de Amin há uma forte tendência de voto nos candidatos que faziam parte da coligação que o apoiava (Paulinho Bornhausen e Hugo Biehl); o mesmo ocorre com Casildo Maldaner e Leonel Pavan, em relação a Luiz Henrique e com Ideli Salvati e Milton Mendes em relação a Fritsch. De toda forma, em todos estes casos há "desvios" significativos: percentuais importantes de eleitores que votavam em cada um dos candidatos a governador não votavam nos dois candidatos vinculados aos partidos que formavam a base de apoio a cada um daqueles candidatos. Isso é mais nítido entre os eleitores de Amin e, a seguir, de Luiz Henrique e, de forma bem menor, entre os eleitores de Fritsch.

\section{As Eleições de 2006}

Santa Catarina foi um dos Estados em que o candidato Geraldo Alckmin foi melhor na eleição presidencial de 2006: enquanto Lula vencia o 1 으 turno em boa parte do país, se dependesse só dos catarinenses Alckmin teria vencido já no 10 turno, com $52,7 \%$ dos votos (contra $30,9 \%$ de Lula). No 2 ㅇ turno ocorreu o mesmo fenômeno que se deu em âmbito nacional: Alckmin perdeu votos entre o 1 을 e 2 o turnos; dessa forma, sua vantagem nas urnas catarinenses diminuiu, no $2 \mathrm{O}$ turno $(50,3 \%$, contra $41,9 \%$ de Lula). $\mathrm{Na}$ eleição para governador, a disputa principal era entre os dois mesmos candidatos de 2002; o candidato à reeleição, Luiz Henrique (que se afastou do governo voluntariamente, no período pré-eleitoral, deixando o cargo nas mãos do seu vice, Eduardo Pinho Moreira, do PMDB), quase consegue liquidar a fatura no 1 으 turno, com $48,9 \%$ dos votos válidos $(44,6 \%$ dos votantes, enquanto seu adversário, Esperidião Amin, fica com 30,9\%). No 2으 turno, embora Amin cresça muito mais que seu oponente, este vence com $47,7 \%$ dos votos, contra os $42,8 \%$ de Amin. Na vaga para Senador, o ex-prefeito de Lages, Raimundo Colombo (PFL), vence, com 53\% dos votos, contra 25,5\% da deputada petista Luci Choinacki.

O gênero (sexo) dos eleitores não foi uma variável relevante no 1ำ turno: as intenções de voto nos diferentes candidatos não variaram significativamente entre o eleitorado masculino e o feminino. ${ }^{21}$ No 2 o turno

\footnotetext{
${ }^{21} \mathrm{Na}$ maioria das análises serão utilizados os dados das pesquisas realizadas pelo Ibope mais próximas ao 1 은 turno e 2 을 turno ( 28 a 30/09/06 e 17 a 19 de outubro, respectivamente). De uma outra pesquisa, realizada entre 12 e 14 de setembro, serão utilizados dados referentes a algumas variáveis para as quais não há dados naquelas anteriores.
} 
da eleição presidencial, o único ponto relevante é que a diferença entre Alckmin e Lula no eleitorado feminino era mais do que o dobro da diferença no eleitorado masculino ( $19 \%$ e $8 \%$, respectivamente). ${ }^{22}$

Quanto à variável idade, no $1 \stackrel{0}{\text { turno houve algumas variações }}$ relevantes, embora nem sempre num mesmo sentido. Cabe apenas destacar que, embora o governador Luiz Henrique vencesse Amin em todas as faixas de idade, sua vitória era muito maior na faixa dos muito jovens (16 e 17 anos). Mesmo não havendo um declínio contínuo de sua vantagem à medida que se passa aos eleitores mais velhos, na faixa dos eleitores com 60 anos ou mais sua vantagem praticamente desaparece, havendo um empate técnico entre os dois candidatos. No $2 \underline{0}$ turno a tendência é ainda mais clara, havendo um declínio contínuo da vantagem de Luiz Henrique (22\% entre os mais jovens, caindo para $5 \%$ entre os mais velhos).

No que respeita à escolaridade dos eleitores, os dados da Tabela 16 mostram que as vitórias de Luiz Henrique sobre Amin e de Alckmin sobre Lula no 1 을 turno se ampliam à medida que passamos dos eleitores menos instruídos para os com maior grau de escolaridade.

Tabela 16: Diferenciais entre os dois principais candidatos nas eleições para governador, senador e presidente, segundo escolaridade dos eleitores (2006)

\begin{tabular}{|c|c|c|c|c|c|c|}
\hline \multirow{2}{*}{ Cargo } & \multirow{2}{*}{ Diferencial } & \multirow{2}{*}{ Total } & \multicolumn{4}{|c|}{ Escolaridade } \\
\hline & & & Até $4^{\mathrm{a}}$ s. & 5 a -8 a $s$. & Médio & Superior \\
\hline Governador ( 1 ㅇt.) & LHS - Amin & 14 & 10 & 11 & 15 & 18 \\
\hline Governador ( $2 \stackrel{\circ}{ }$ t. $)$ & LHS - Amin & 15 & 5 & 21 & 20 & 9 \\
\hline Presidente ( $1 \stackrel{\circ}{t}$. $)$ & Alckmin - Lula & 15 & 2 & 9 & 22 & 33 \\
\hline Presidente ( $2 \circ$ t.) & Alckmin - Lula & 13 & 9 & 9 & 15 & 25 \\
\hline Senador & Colombo - Luci & 22 & 18 & 22 & 18 & 27 \\
\hline
\end{tabular}

Fonte: 1 은 turno: Ibope (OPP354 - 28 a 30/09/06); 2을 turno: Ibope (OPP421 - 17 a 19/10/06).

No $2^{\circ}$ turno a tendência permanece a mesma na eleição presidencial; na eleição para governador há uma reversão desta tendência na faixa de maior escolaridade. Na eleição para senador não há uma tendência tão clara, mas a vitória de Colombo (PFL) sobre Luci Choinacki (PT) também foi maior entre os eleitores com nível superior de escolaridade. No caso das eleições envolvendo diretamente candidatos petistas (presidência e senado),

22 Nesta seção os dados serão apresentados a partir da análise da possível influência de cada uma das variáveis sobre as intenções de voto para todos os cargos em estudo (presidente, governador e senador) simultaneamente. 
esta tendência pode estar associada à maior rejeição ao PT e ao governo Lula, por parte dos eleitores de maior escolaridade, após o "mensalão". No 2 o turno, como em todo o país, Lula reverte parcialmente esta rejeição, melhorando seu desempenho no conjunto do eleitorado, especialmente entre os mais educados, em comparação com sua votação no $1 \stackrel{0}{\text { turno. }}$

As tendências acima não se repetem em relação à renda dos eleitores. Nas eleições para governador ( $1 \stackrel{0}{\text { e }} 2^{\underline{O}}$ turnos) e senador, não há nenhuma variação significativa das intenções de voto, à medida que varia a renda. Apenas na eleição presidencial ocorre a tendência de maior vantagem de Alckmin entre os mais ricos, embora com algumas variações entre o 1 으 e o 2 o turnos.

No que se refere à eleição para governador, há uma variação importante nas intenções de voto entre os dois principais candidatos, segundo a "raça" ("cor") dos eleitores: enquanto no 1을 turno a vantagem a favor de Luiz Henrique era bem maior entre pretos e pardos do que entre os brancos, no $2 \underline{0}$ turno a vantagem deste candidato sobre seu adversário não varia muito com a "raça" dos eleitores; há até uma vantagem um pouco maior entre os brancos (Tabela 17). ${ }^{23}$

Tabela 17: Diferenciais entre dois principais candidatos nas eleições para governador, senador e presidente, segundo "raça" ("cor") dos eleitores (1으 e 2 o turnos - 2006)

\begin{tabular}{|c|c|c|c|c|}
\hline \multirow{2}{*}{ Cargo } & \multirow{2}{*}{ Diferencial } & \multirow{2}{*}{ Total } & \multicolumn{2}{|c|}{ "Raça” (“Cor”) } \\
\hline & & & Branca & Preta/Parda \\
\hline Governador ( $1 \stackrel{\circ}{\mathrm{o}} \mathrm{t})$ & LHS - Amin & 23 & 20 & 34 \\
\hline Governador ( $2 \mathrm{o}$ t. $)$ & LHS - Amin & 15 & 15 & 12 \\
\hline Presidente ( 10 t.) & Alckmin - Lula & 4 & 8 & -12 \\
\hline Presidente ( $2 \circ \mathrm{o}$ t.) & Alckmin - Lula & 13 & 20 & -7 \\
\hline Senador & Colombo - Luci & 18 & 20 & 13 \\
\hline
\end{tabular}

Fonte: 1 을 turno: Ibope (OPP309 - 12 a 14/09/06); $2^{\circ}$ turno: Ibope (OPP421 - 17 a 19/10/06).

Quanto à eleição presidencial, o fenômeno que ocorreu no país como um todo - a melhor votação de Lula entre pretos e pardos (ver Carreirão, 2007a, entre outros) - se repete de forma pronunciada em Santa Catarina. Esta vantagem foi tão grande, a ponto de inverter a situação: nos dois turnos, enquanto Alckmin vencia por boa margem entre os brancos, Lula vencia também por uma boa diferença entre pretos e pardos.

$\overline{{ }^{23} \text { O Ibope não apresenta }}$ os dados de pretos e pardos separadamente. 
Quanto à religião dos eleitores, no conjunto das eleições de 2006 a influência da religião dos eleitores sobre seu voto, além de não ser de grande magnitude, não teve um sentido unívoco.

A análise da Tabela 18 revela associação substancial entre as intenções de voto para governador e a avaliação que os eleitores faziam do desempenho do governo em exercício. ${ }^{24}$

\section{Tabela 18: Intenção de voto (\%) para governador (1ำ turno) segundo avaliação do governador (2006)}

\begin{tabular}{lcccc}
\hline \multirow{2}{*}{ Candidato } & \multirow{2}{*}{ Total } & \multicolumn{3}{c}{ Avaliação do Governador } \\
\cline { 3 - 5 } & & Ótimo/Bom & Regular & Ruim/Péssimo \\
\hline Amin (PP) & 26 & 15 & 31 & 39 \\
Fritsch (PT) & 8 & 4 & 9 & 15 \\
L.Henrique (PMDB) & 49 & 71 & 44 & 20 \\
\hline
\end{tabular}

Fonte: Ibope (OPP309 - 12 a 14/09/06).

Obs: Demais candidatos tinham 1\% ou menos de intenções de voto.

O governador, candidato à reeleição, vencia de forma folgada entre os eleitores que avaliavam seu governo positivamente; vencia por margem mais apertada entre eleitores que o avaliavam como regular e era derrotado por Amin no conjunto dos eleitores que julgavam seu governo ruim ou péssimo. Isso acontece também no $2^{\mathrm{O}}$ turno. Comparando com o que acontecia em 2002, Luiz Henrique foi muito melhor em 2006 entre eleitores que avaliavam seu governo como regular, ruim ou péssimo, do que foi Amin naquela eleição entre eleitores que faziam este tipo de avaliação de sua gestão.

No que se refere à transferência de voto entre os dois turnos, na eleição para governador grande parte dos eleitores de Amin e de Luiz Henrique

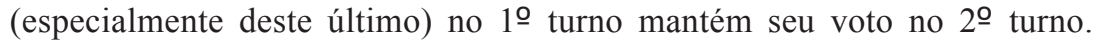
Novamente, como em 2002, há uma taxa de reversão de voto maior de Amin para Luiz Henrique, entre o $1 \stackrel{0}{\text { turno e o } 2}$, do que a que ocorre em sentido inverso. Os eleitores de Fritsch se dividem, com uma parcela maior

\footnotetext{
${ }^{24}$ Como já foi dito, Luiz Henrique havia se afastado do governo no período pré-eleitoral, deixando o cargo nas mãos do seu vice, Eduardo Pinho Moreira. A pergunta sobre avaliação de governo mencionava nominalmente este último, o que pode ter contribuído para que as correlações entre avaliação de governo e voto fossem um pouco menores do que o usual, no caso de candidatos à reeleição. As correlações (Gama) foram de 0,51 no 1 으 turno e de 0,55 no $2^{\circ}$. As variáveis foram assim operacionalizadas: avaliação do governo: $1=$ ruim + péssimo; $2=$ regular; $3=$ bom + ótimo. As respostas "Não Sabe" foram eliminadas da análise (missing cases). Variável intenção de voto: 1 = voto nos candidatos de oposição $(2$ 은 turno = Amin $) ; 2$ = voto em Luiz Henrique da Silveira.
} 
votando em Amin, no $2 \underline{0}$ turno, seguindo a direção indicada pelo candidato. Os eleitores que votaram nos demais candidatos que disputaram o $1 \underline{0}$ turno também vão dar uma vantagem para Amin no 2으 turno (embora menor do que a dos eleitores de Fritsch). Embora estas transferências tenham reduzido a diferença entre os dois principais candidatos, não foram suficientes para a reversão do resultado do 1 으 turno. Vale destacar que em 2006 houve uma mudança na indicação de voto para o $2^{\circ}$ turno feita pelo PT (ou pelo menos por parte de seu candidato ao governo), em relação a 2002. Enquanto em 2002 o partido indicou apoio a Luiz Henrique no 2o turno, em 2006, indicou apoio a Amin. Embora segmentos do partido tenham utilizado também, como justificativa, o argumento de que na eleição anterior eles haviam apoiado o candidato peemedebista e estavam se sentindo insatisfeitos com os rumos tomados por seu governo, a motivação central parece ter sido realmente a tentativa de obter o apoio de Amin a Lula no 2으 turno, já que Luiz Henrique apoiava claramente Alckmin. $\mathrm{O}$ apoio do candidato petista a Amin, no 2 o turno, embora possa ser compreendido à luz da conjuntura eleitoral, representa uma inconsistência, se analisado do ponto de vista ideológico, com base na classificação usual dos partidos numa escala esquerda-direita (já que deste ponto de vista, um partido de esquerda "deveria" apoiar um partido de centro e não um de direita).

Quanto ao cruzamento dos votos para governador e presidente no 2 o turno, não houve nenhuma associação significativa entre os votos para os dois cargos, já que os percentuais de votos obtidos por Alckmin e Lula entre eleitores de Amin não são muito diferentes dos obtidos entre eleitores de Luiz Henrique.

\section{Considerações finais}

Concluindo, mesmo considerando as limitações dos dados, foi possível examinar a possível influência de algumas variáveis sobre o voto. Entre as variáveis socioeconômicas, o sexo (gênero) dos eleitores teve muito pouca influência na sua decisão de voto (com exceção do $2 \underline{0}$ turno da eleição presidencial de 2006, em que a vantagem de Alckmin sobre Lula foi bem maior entre as mulheres), de forma semelhante ao que ocorre em âmbito nacional. A escolaridade e a renda dos eleitores tiveram algum peso na decisão de voto em algumas eleições, mas sem um sentido unívoco no conjunto dos pleitos em estudo. Não é possível, a partir dos dados analisados, corroborar hipóteses formuladas em âmbito nacional ou internacional, no sentido de maior votação de candidatos de esquerda entre os eleitores mais 
pobres e com menor nível de instrução formal. Quanto à idade, embora com algumas exceções, a tendência mais recorrente foi a de maior votação dos candidatos mais à esquerda entre os eleitores mais jovens. A ocupação dos eleitores teve certa associação com o voto, na única eleição para a qual temos dados (1998). Candidatos de centro ou direita foram bem junto aos empresários e mal junto aos funcionários públicos e profissionais liberais; o inverso acontecia com candidatos de esquerda. Quanto à associação entre a "raça" (ou "cor") dos eleitores e seu voto nas eleições de 2006, embora essa associação não tenha tido um único sentido nas disputas para os diferentes cargos, naquelas disputas onde havia uma polarização ideológica maior os candidatos de direita ou centro obtiveram melhores votações entre os eleitores brancos, enquanto os candidatos à esquerda tinham melhores votações entre pretos e pardos.

Quanto às variáveis propriamente políticas, no que se refere à preferência partidária, embora seja manifestada apenas por cerca de $45 \%$ dos eleitores e embora entre estes últimos haja parcela razoável que não vote partidariamente, a grande maioria dos eleitores que manifestam preferência por PT e PSDB (e em menor grau PP e PFL) votam em conformidade com essa preferência. Mas, a variável que se mostrou mais relevante foi a avaliação de governo: a votação em um candidato que representa a continuidade do governo (nacional ou estadual) em exercício está fortemente associada à avaliação que os eleitores fazem deste governo. Embora esta avaliação seja em parte influenciada pelas preferências partidárias dos eleitores, em grande medida, porém, ela parece ser feita em bases "técnicas", sem levar em consideração estas preferências. Eleitores que avaliam bem um governo tendem a votar no candidato que representa a continuidade deste governo; os eleitores que avaliam mal o governo tendem a votar em candidatos da oposição.

Por fim, no que se refere à consistência ideológica do voto em eleições para diferentes cargos, ou entre um turno e outro do mesmo cargo, embora a tendência mais geral seja a haver certo grau de consistência, há também um percentual não desprezível de eleitores que votam em candidatos "ideologicamente" distantes, para diferentes cargos numa mesma eleição, ou transferem seu voto, no 2 o turno, para um candidato de partido "ideologicamente" diferente do partido daquele candidato em que tinham votado no 1 으 turno, para um mesmo cargo. Embora não se possa pleitear que o eleitorado catarinense seja totalmente coerente ideologicamente, não se pode, por outro lado, afirmar que o conjunto do eleitorado, ao decidir seu voto, seja totalmente alheio às diferenças ideológicas entre partidos e candidatos. Nisso ele não $\mathrm{s}$ e diferencia do eleitorado brasileiro. 


\section{Referências}

ALMEIDA, Alberto. Ideologia e comportamento eleitoral: evidências de que a ideologia não é importante para explicar o voto. 25을 Encontro Anual da Anpocs. Caxambu, 2001.

CARREIRÃO, Yan S. Avaliação do governo e "voto econômico". Lua Nova, São Paulo, n. 48. p. 213-232, 1999.

. A decisão de voto nas eleições presidenciais brasileiras. Rio de Janeiro/ Florianópolis: FGV/Edufsc, 2002a

. Identificação ideológica e voto para presidente. Opinião Pública, Campinas, v. 8, n. 1, p. $54-79,2002$ b.

. Ideologia e partidos políticos: um estudo sobre coligações em Santa Catarina.

Opinião Pública, Campinas, v. 12, n. 1, p. 136-163, 2006.

. A eleição presidencial de 2006: uma análise preliminar. Política \& Sociedade, Florianópolis, n. 10, p. 70-101, 2007a.

. Identificação ideológica, partidos e voto na eleição presidencial de 2006. Opinião Pública, Campinas, v. 13, n. 2, p. 307-339, 2007 b.

CARREIRÃO, Yan; KINZO, Maria D. G. Partidos políticos, preferência partidária e decisão eleitoral no Brasil (1989-2002). Dados, Rio de Janeiro, v. 47, n. 1, p. 131-168, 2004.

CARVALHO, José Murilo. Eleições em tempo de cólera. Cadernos de Conjuntura, Rio de Janeiro: Iuperj, n. 20, 1989.

CLARKE, Harold; STEWART, Marianne. The decline of parties in the minds of citizens. Annual Review of Political Science, v. 1, p. 357-378, 1998.

DALTON, Russell J.; WATTENBERG, Martin (Eds.). Parties without partisans: political changes in advanced industrial democracies. Oxford: Oxford University Press, 2000 .

ECHEGARAY, Fabian. Economic Crisis and electoral responses in Latin America. Lanham: University Press of America, 2005.

FIGUEIREDO, M. A lei de ferro da competição eleitoral: a aritmética eleitoral. Cadernos de Conjuntura, Rio de Janeiro, Iuperj, n. 50, jul. 1994.

FIORINA, Morris. Retrospective voting in American national elections. New Haven: Yale University Press, 1981.

KEY, V. O. The responsible electorate: rationality in presidential voting, 1936-1966. Cambridge: Belknap Press, 1966.

LEWIS-BECK, Michael. Economics \& elections: the major Western democracies. Ann Arbor: The University of Michigan Press, 1988.

LIPSET, Seymour M. O homem político. Rio de Janeiro: Zahar, 1967.

POPKIN, Samuel L. The reasoning voter: comunication and persuasion in presidential campaigns. 2. ed. Chicago: The University of Chicago Press, 1994. 
RAHN, Wendy et al. A social-cognitive model of candidate appraisal. In: J. FEREJOHN; J. KUKLINSKI (Eds.). Information and democratic processes, Illinois: University of Illinois Press, 1990.

RENNÓ, Lúcio. Escândalos e voto: as eleições presidenciais brasileiras de 2006. Opinião Pública, Campinas, v. 13, n. 2, p. 260-282, 2007.

SINGER, André. Esquerda e direita no eleitorado brasileiro. São Paulo: Edusp, 2000. . Collor na periferia: a volta por cima do populismo. In: LAMOUNIER, Bolívar (Org.). De Geisel a Collor: o balanço da transição. São Paulo: Sumaré/Idesp, 1990.

SOARES, Gláucio A. D. Sociedade e política no Brasil. São Paulo: Difel, 1973. . A democracia interrompida. Rio de Janeiro: Ed. FGV, 2001.

VEIGA, Luciana. Os partidos brasileiros na perspectiva dos eleitores: mudanças e continuidades na identificação partidária e na avaliação das principais legendas após 2002. Opinião Pública, Campinas, v. 13, n. 2, p. 340-365, 2007.

WEISBERG, Herbert; GREENE, Steven. The political psychology of party identification. In: MacKUEN, Michael; RABINOWITZ, George (Eds.). Electoral democracy. Ann Arbor: The University of Michigan Press, 2003.

\section{Apêndice metodológico: pesquisas de opinião utilizadas}

a) Pesquisas obtidas junto ao Centro de Estudos de Opinião Pública (Cesop - Unicamp):

1. DATAFOLHA/SC98 SET-0886 - Título da Pesquisa: Avaliação Governo FHC... Intenção de voto governador e senador $\mathrm{SC}-24 / 09 / 08-\mathrm{N}=1508$.

http://www.cesop.unicamp.br/busca/CESOP/pesquisa_usuario_visualizar?id pesq $=1038$

2. DATAFOLHA/SC98 SET-0899 - Título da Pesquisa: Avaliação Governo FHC... Intenção de voto governador e senador $\mathrm{SC}-18 / 09 / 08-\mathrm{N}=1488$.

http://www.cesop.unicamp.br/busca/CESOP/pesquisa_usuario_visualizar?id pesq $=1051$

3. IBOPE/SC98 SET-1252 - Título da Pesquisa: Projeto Globo 98 - $7^{\text {a }}$ Rodada $15 / 09 / 08-\mathrm{N}=1600$.

http://www.cesop.unicamp.br/busca/CESOP/pesquisa_usuario_visualizar?id_ pesq $=514$

4. IBOPE/SC02 SET-1789 - Título da Pesquisa: Globo 4ªRodada - 25/09/02 $\mathrm{N}=1600$.

http://www.cesop.unicamp.br/busca/CESOP/pesquisa_usuario_visualizar?id pesq $=1813$

5. IBOPE/SC06 SET-2463 - Título da Pesquisa: Pesq. Opinião Pública sobre Assuntos Políticos/Administrativos - 29 a 30/09/06 - N=1610 (página ainda não catalogada). 
6. IBOPE/SC06 SET-2465 - Título da Pesquisa: Pesq. Opinião Pública sobre Assuntos Políticos/Administrativos - 17 a 19/10/06 - N=1610 (página ainda não catalogada).

b) Pesquisas obtidas junto ao site do Ibope:

1. Título da Pesquisa: Pesq. Opinião Pública sobre Assuntos Políticos/Administrativos - OPP - 23 a 25/09/02 - N=1200.

http://www2.ibope.com.br/CalandraKBX/filesmng.nsf/Eleicoes/2002/Downloads/ eleicoes_2002_sc_opp395_00.pdf/\$File/eleicoes_2002_sc_opp395_00.pdf

2. Título da Pesquisa: Pesq. Opinião Pública sobre Assuntos Políticos/Administrativos - OPP309 - 12 a 14/09/06 - N=1204.

http://www.ibope.com.br/Eleicoes/2006/download/opp309_santacatarina_set06.pdf

Recebido em: 31 maio 2008 Aprovado em: 16 set. 2008 